\section{Increasing Seedling Density, Age, and Nitrogen Fertilization Increases Onion Yield}

\author{
Catur Herison ${ }^{1}$, Joseph G. Masabni ${ }^{1}$, and Bernard H. Zandstra ${ }^{2}$ \\ Department of Horticulture, Michigan State University, East Lansing, MI 48824
}

Additional index words. Allium cepa, transplant production

\begin{abstract}
Three onion (Allium cepa $\mathrm{L}$.) cultivar transplants were grown in the greenhouse in 200-cell plastic trays with one, two, or three plants per cell; at 75, 150, or $225 \mathrm{ppm} \mathrm{N}$; and for 8, 10, or 12 weeks. Increasing the number of plants per cell resulted in smaller seedlings at transplanting and reduced time to maturity in the field by 1 week. Two and three plants per cell yielded more bulbs $\geq 76 \mathrm{~mm}$ in diameter, but one plant per cell had the highest percentage of bulbs $\geq 102 \mathrm{~mm}$ in diameter. Older seedlings and higher $\mathbf{N}$ applications produced larger plants at transplant and larger bulbs at harvest. Increasing $\mathbf{N}$ applications reduced maturation time slightly. Bulb fresh weight at harvest and yield of bulbs $\geq 76 \mathrm{~mm}$ in diameter were highest with 10- and 12-week-old transplants, and at 150 and 225 ppm N.
\end{abstract}

Spanish onions grown in Michigan usually are field-grown transplants from southern states shipped north in early to mid-April. Wet field conditions in Michigan often prevent planting for several weeks, and transplant quality declines rapidly during storage. Growers are searching for alternative plant sources that would be more manageable. In addition, the Michigan vegetable industry is rapidly converting from field-grown bare-rooted plants to greenhouse-grown cell plants. Dependable transplanters that can set the cell plants in the field are available.

Total onion yield increases, but bulb size decreases, as plant population increases (McGeary, 1985). Onions produce large bulbs when spaced widely and smaller bulbs when planted densely (Davis and Jones, 1944); however, they can push out into available space to some extent, even if planted close together. The number of onion plants per cell may be increased to take advantage of their ability to use space in the field, and at the same time reduce the space needed to produce plants in the greenhouse.

Local greenhouses may be good sources of onion transplants, but, to our knowledge, no information is available concerning onion production in cells in the greenhouse. The studies reported here were conducted to determine the effects of cultivar, number of plants per cell, plant age at transplanting, and $\mathrm{N}$ application in the greenhouse on onion production in the field.

Received for publication 24 Jan. 1992. Accepted for publication 11 Sept. 1992. We acknowledge the Michigan Agricultural Experiment Station for its support of this research. The cost of publishing this paper was defrayed in part by the payment of page charges. Under postal regulations, this paper therefore must be hereby marked advertisement solely to indicate this fact.

${ }^{1}$ Research Assistant.

${ }^{2}$ Professor; to whom reprint requests should be addressed.
Two studies were conducted: a cell plant population study, and a cell plant age and $\mathrm{N}$ fertilization study. Three cultivars-Sweet Sandwich, Vega, and Yula-were compared in both experiments.

In the plant population study, onions were seeded on 18 Feb. 1990 in 200-cell $\left(4.6 \mathrm{~cm}^{3}\right)$ plastic trays $(28 \times 56 \mathrm{~cm})$ (Blackmore Transplanter Co., Ypsilanti, Mich.) containing a commercial peat-perlite-vermiculite mix (Baccto Professional Planting Mix, Michigan Peat Co., Houston). The plants were grown in the greenhouse at Michigan State Univ., East Lansing, at a mean temperature of $18 \mathrm{C}$ (day) and $13 \mathrm{C}$ (night), and under a natural photoperiod of 11 to $13 \mathrm{~h}$. No supplemental lighting was used. Two, three, or five seeds were planted in each cell, one population per tray. Two weeks later, the seedlings were thinned to one, two, or three plants per cell, respectively. Beginning 2 weeks after seeding, the cells were saturated weekly with $20 \mathrm{~N}-8.6 \mathrm{P}-16.6 \mathrm{~K}$ (375 mg.liter ${ }^{-1}$ ). The plants were watereddaily as needed, with extra care taken to ensure that 12 weeks after seeding.

${ }^{\mathrm{z}}$ Each value is the mean of all plants from 120 cells.

${ }^{y}$ Interaction between main effects was not significant. all plants were watered equally. Twelve weeks after seeding, the height and fresh and dry weights of plants from 10 cells of five separate trays of each population were measured.

The onion seedlings were transplanted into the field on 15 May 1990 at the Michigan State Univ. Muck Research Farm, Laingsburg, with a Mechanical Transplanter (Holland, Mich.) model 4000 . The individual study plots were $7.6 \mathrm{~m}$ long, $1.5 \mathrm{~m}$ wide, and consisted of two rows $76 \mathrm{~cm}$ apart. The cells containing one, two, or three onion plants were set $15 \mathrm{~cm}$ apart in the rows. Individual plants from multiplant cells were not separated. The soil was a Houghton muck (euic, mesic, Typic Medisaprist), $\mathrm{pH} 6.3$, with $80 \%$ organic matter. The experiment was a randomized complete block with a $3 \times 3$ factorial arrangement (cultivar $\times$ number of plants per cell) and four replications.

Preplant fertilizer was applied in the field at $80 \mathrm{~kg} \mathrm{~N}, 86 \mathrm{~kg} \mathrm{P}$, and $174 \mathrm{~kg} \mathrm{~K} / \mathrm{ha}$. The onions were top-dressed with $103 \mathrm{~kg} \mathrm{~N} / \mathrm{ha}$ on 25 June. Plots were sprinkler-irrigated as needed, and standard cultural practices were used to control pests.

The experimental plants were harvested on 5 Sept. The onions from $5 \mathrm{~m}$ of both rows in each plot were pulled and topped by hand. Total fresh weight of bulbs was recorded, and the bulbs then were placed in $0.045-\mathrm{m}^{3}$ onion storage crates. The onions were cured for 4 weeks in a well-ventilated building that ranged from 7 to $27 \mathrm{C}$.

The onions were then graded by diameter into size classes similar to commercial Spanish onion classes: medium ( $<76 \mathrm{~mm})$, large (76-102 mm), colossal (>102-127 mm), or supercolossal $(>127 \mathrm{~mm})$. The bulbs were weighed and the percentage of the weight of each size class to the total weight at grading was calculated. The diameter and length of 20 bulbs $\geq 76 \mathrm{~mm}$ from each plot were measured to determine the diameter : length $(\mathrm{D} / \mathrm{L})$ ratio. The data were subjected to analysis of variance and trend analysis. Percentage data were arcsin-transformed for analysis.

In the seedling age and $\mathrm{N}$ fertilization study, seeds of the same three cultivars were sown in

Table 1. Effects of cultivar and number of plants per cell on onion seedling size and weight at transplanting,

\begin{tabular}{|c|c|c|c|c|}
\hline Variable $^{y}$ & $\begin{array}{l}\text { Shoot ht }{ }^{\mathrm{z}} \\
(\mathrm{cm})\end{array}$ & $\begin{array}{c}\text { Shoot } \\
\text { fresh wt } \\
(\mathrm{g})\end{array}$ & $\begin{array}{c}\text { Root } \\
\text { fresh wt } \\
\text { (g) }\end{array}$ & $\begin{array}{l}\text { Root : shoot } \\
\text { ratio }^{2} \\
\text { (dry wt) }\end{array}$ \\
\hline \multicolumn{5}{|l|}{$\overline{\text { Cultivar }}$} \\
\hline Sweet Sandwich & 9.3 & 0.63 & 0.33 & 0.42 \\
\hline Yula & 11.4 & 0.93 & 0.35 & 0.33 \\
\hline Vega & 10.3 & 0.85 & 0.36 & 0.35 \\
\hline LSD $(0.05)$ & 1.1 & 0.19 & NS & 0.06 \\
\hline \multicolumn{5}{|l|}{ No. plants per cell } \\
\hline 1 & 10.7 & 1.04 & 0.47 & 0.40 \\
\hline 2 & 10.3 & 0.77 & 0.32 & 0.36 \\
\hline 3 & 10.0 & 0.59 & 0.24 & 0.34 \\
\hline Significance & $\mathrm{L}^{*}$ & $\mathrm{~L}^{* *}$ & $\mathrm{~L}^{* *} \mathrm{Q}^{*}$ & $\mathrm{~L}^{*}$ \\
\hline \multicolumn{5}{|l|}{ Contrasts } \\
\hline 1 vs. 2 & NS & $* *$ & $* *$ & NS \\
\hline 2 vs. 3 & NS & ** & ** & NS \\
\hline
\end{tabular}

ss,",***Nonsignificant or significant at $P=0.05$ or 0.01 , respectively. Linear (L) or quadratic (Q) response. 
Table 2. Effects of cultivar and number of onion transplants per cell on bulb maturity, fresh weight, size, and shape.

\begin{tabular}{|c|c|c|c|c|c|c|c|c|c|}
\hline \multirow[b]{2}{*}{ Variable $^{w}$} & \multirow{2}{*}{$\begin{array}{l}\text { Maturity } \\
\text { (wk) }\end{array}$} & \multirow{2}{*}{$\begin{array}{c}\text { Bulb } \\
\text { fresh wt } \\
\text { (kg/plot) }\end{array}$} & \multicolumn{5}{|c|}{$\begin{array}{c}\text { Bulb size (mm) } \\
\text { (\% by wt at grading) })^{y}\end{array}$} & \multirow{2}{*}{$\begin{array}{c}\text { Yield } \\
\text { of bulbs } \\
\geq 76 \mathrm{~mm} \\
\left(\mathrm{t} \cdot \mathrm{ha}^{-1}\right)\end{array}$} & \multirow{2}{*}{$\begin{array}{l}\text { Bulb } \\
\text { shape }^{x} \\
\text { (D/L) }\end{array}$} \\
\hline & & & $<76$ & $76-102$ & $>102-127$ & $>127$ & Cull & & \\
\hline \multicolumn{10}{|l|}{ Cultivar } \\
\hline $\mathrm{SS}^{v}$ & 15.0 & 47.4 & 12.3 & 76.1 & 11.1 & 0 & 0.4 & 47.9 & 0.97 \\
\hline Yula & 13.6 & 50.1 & 8.8 & 58.8 & 26.6 & 1.4 & 4.4 & 52.0 & 0.99 \\
\hline Vega & 15.8 & 48.3 & 9.7 & 66.8 & 20.4 & 0.2 & 2.7 & 49.7 & 0.97 \\
\hline LSD $(0.05)$ & 0.3 & NS & 2.6 & 6.9 & 6.5 & NS & 2.1 & 3.2 & 0.02 \\
\hline \multicolumn{10}{|l|}{ No. plants } \\
\hline 1 & 15.3 & 35.8 & 0.9 & 48.7 & 44.2 & 1.7 & 4.5 & 40.5 & 1.12 \\
\hline 2 & 14.8 & 50.7 & 7.0 & 80.8 & 10.3 & 0.0 & 1.9 & 54.6 & 0.95 \\
\hline 3 & 14.4 & 59.2 & 23.0 & 72.2 & 3.6 & 0.0 & 1.2 & 54.3 & 0.87 \\
\hline Significance & $\mathrm{L}^{* *}$ & $\mathrm{~L}^{* *} \mathrm{Q}^{*}$ & $\mathrm{~L}^{* *} \mathrm{Q}^{* *}$ & $\mathrm{~L}^{* *} \mathrm{Q}^{* *}$ & $\mathrm{~L}^{* *} \mathrm{Q}^{* *}$ & $\mathbf{L}^{*}$ & $\mathrm{~L}^{* *}$ & $\mathrm{~L}^{* *} \mathrm{Q}^{* *}$ & $\mathrm{~L}^{* *} \mathrm{Q}^{* *}$ \\
\hline \multicolumn{10}{|l|}{ Contrasts } \\
\hline 1 vs. 2 & $*$ & ** & $*$ & ** & $* *$ & $*$ & ** & ** & $* *$ \\
\hline 2 vs. 3 & NS & $* *$ & NS & $*$ & $*$ & NS & NS & NS & $* *$ \\
\hline
\end{tabular}

${ }^{\mathrm{z}}$ Maturity defined as $25 \%$ of leaves lying down.

yercentage data were transformed by $\arcsin \sqrt{ }(y+1)$ for analysis; actual values are presented.

${ }^{x}$ Diameter divided by length: $\mathrm{D} / \mathrm{L}<1$, tall; $\mathrm{D} / \mathrm{L}=1$, spherical; $\mathrm{D} / \mathrm{L}>1$, flat.

"Interaction between main effects was not significant.

'SS = 'Sweet Sandwich'.

ws,", Nonsignificant or significant at $P=0.05$ or 0.01 , respectively. Linear (L) or quadratic (Q) response.

200-cell trays on 20 Feb., 6 Mar., and 20 Mar. 1990 in the greenhouse for field transplanting on 18 May 1990, which resulted in 12-, 10-, and 8-week-old seedlings at transplanting. One seed was planted in each cell. Seedlings were fertilized weekly with 75,150 , or $225 \mathrm{ppm} \mathrm{N}$. A complete $20 \mathrm{~N}-8.6 \mathrm{P}-16.6 \mathrm{~K}$ fertilizer plus urea were used to provide the desired $\mathrm{N}$ and maintain uniform $\mathrm{P}$ and $\mathrm{K}$ levels in the trays. Plants were watered as needed. On 14 May, 10 plants from four separate trays of each treatment were harvested, sized, and weighed as described previously.

All cultural practices were the same as in the previous experiment. This experiment was a randomized complete block with a $3 \times 3 \times 3$ factorial arrangement of cultivar, seedling age, and $\mathrm{N}$ level, with four replications. Plot size was the same as above. The onions were harvested 7 Sept., cured, and graded as described above.

'Yula' plants were taller than 'Sweet Sandwich' and 'Vega' plants and had a higher fresh weight than 'Sweet Sandwich' at transplanting (Table 1). Root fresh weight at transplanting did not differ among cultivars. 'Sweet Sandwich' had the highest root : shoot ratio, which indicated that it had developed a proportionally larger root system than the other cultivars. 'Sweet Sandwich' is a pungent $x$ Spanish cross and grows slowly early in the season, similarly to pungent onions. The true Spanish cultivars Yula and Vega were more vigorous and produced larger shoots early in their life cycle.

The number of plants per cell significantly affected shoot height and fresh weight and root fresh weight. These measurements decreased linearly as the number of plants per cell increased from one to three. Single plants had the highest root : shoot ratio, probably because of a lack of competition for root space in the cells.

'Yula' matured 13.6 weeks after transplanting - about 1.5 to 2 weeks earlier than
'Sweet Sandwich' or 'Vega' (Table 2). Bulb fresh weight at harvest did not differ among cultivars. 'Yula', however, produced more bulbs $\geq 76 \mathrm{~mm}$ in diameter than 'Sweet Sandwich', which produced more bulbs $<76 \mathrm{~mm}$ in diameter, reflecting its pungent parentage. 'Yula' bulbs were almost spherical, while 'Sweet Sandwich' and 'Vega' were slightly elongated.

Increasing the number of plants per cell hastened onion maturity. Onions from threeplant cells matured $\approx 1$ week earlier than onions from single-plant cells. This was expected, since Jones (1930) and McGeary (1985) reported that crowding in the field hastened onion maturity, and Chung (1989) reported that several plants per container slowed onion maturity. As the number of plants per cell increased, bulb fresh weight increased linearly (Table 2); however, a significant quadratic response indicated that the increase in fresh weight with more plants per cell leveled off. McGeary (1985) reported that onion yields leveled off and then declined as populations increased. Thus, more than three plants per cell may have resulted in no increase or a decrease in bulb fresh weight. Bulb size decreased with the increase in plants per cell: $23 \%$ of the bulbs from cells with three plants and $0.9 \%$ of the bulbs from cells with one plant were $<76 \mathrm{~mm}$ in diameter. Yield of bulbs $\geq 102$ mm was the opposite: $45.9 \%$ of the bulbs from cells with one plant, $10.3 \%$ of the bulbs from cells with two plants, and $3.6 \%$ of the bulbs from cells with three plants were $\geq 102 \mathrm{~mm}$ in diameter.

Total marketable yield is important in addition to large bulb size in onion production. When all bulbs $\geq 76 \mathrm{~mm}$ were combined, plants in cells with two and three plants had higher yields than plants in cells with one plant. Thus, although plants in cells with three plants produced a higher percentage of bulbs $<76 \mathrm{~mm}$ than plants in cells with one or two plants, they also produced a higher percentage of bulbs $\geq 76 \mathrm{~mm}$ than plants in cells with one plant.

Spacing in the cell affected bulb shape. Plants in cells with one plant produced slightly flat bulbs, while plants in cells with two or three plants produced slightly elongated bulbs. Although spherical bulbs are most desirable in the marketplace, slightly elongated bulbs are acceptable. Plants in cells with three plants produced bulbs that were obviously elongated and probably would not have been acceptable in the marketplace.

In the second experiment, 'Sweet Sandwich' had the shortest plants and the lowest shoot fresh weight at transplanting (Table 3). Root fresh weight and root : shoot ratio did not differ among cultivars. Shoot height and fresh weight and root fresh weight at transplanting increased linearly as age increased from 8 to 12 weeks. A significant quadratic response for shoot height and fresh weight indicated that the seedlings had grown proportionally more during the last 2 weeks of development.

Shoot height and fresh weight and root fresh weight increased linearly as $\mathrm{N}$ applications increased from 75 to 225 ppm (Table 3). The root : shoot ratio declined linearly with increased $\mathrm{N}$. This decline was the result of a greater proportional increase in shoot weight vs. root weight as $\mathrm{N}$ level increased.

There was a significant interaction between cultivar and age for shoot fresh weight. This result was due to a greater size increase for 'Yula' and 'Vega' between 10 and 12 weeks than for 'Sweet Sandwich'. A significant interaction for root : shoot ratio was due to an increase in size between 8 to 12 weeks for 'Sweet Sandwich' and a decrease in size for 'Yula' and 'Vega' during the same period. Since root fresh weight increased similarly for the three cultivars, the difference in root : shoot ratio reflected the slower shoot growth of 'Sweet Sandwich'.

The age $\times \mathrm{N}$ interactions were significant for shoot height and fresh weight (Table 3 ). The height interaction was due to a slight decrease in the growth rate of 8-week-old seedlings as the $\mathrm{N}$ application rate increased from 150 to $225 \mathrm{ppm}$. The young plants probably could not assimilate the extra $\mathrm{N}$ rapidly enough, and their growth was slowed slightly; however, their height continued to increase. The fresh weight interaction was due to a slight decrease in weight gain rate for 10week-old plants as the $\mathrm{N}$ application rate increased from 150 to $225 \mathrm{ppm}$. Actual fresh weights continued to increase. Since the decrease was slight, it is probably similar to the height interaction at 8 weeks, or it may be an anomaly.

The cultivar yield response was similar to that in the previous experiment (Table 4). 'Yula' matured first. Since all plants in this experiment were planted singly, each bulb had sufficient growing space, and only $\approx 1 \%$ of the bulbs had a diameter $<76 \mathrm{~mm}$. About $1 \%$ of the single bulbs in the previous experiment was also $<76 \mathrm{~mm}$ in diameter. 'Sweet Sandwich' produced almost twice as many 76- to 102 $\mathrm{mm}$ bulbs as did 'Yula' and $\approx 50 \%$ more than 'Vega'. The latter cultivars produced more 102- to $127-\mathrm{mm}$-diameter bulbs than 'Sweet 
Sandwich'. The smaller 'Sweet Sandwich' bulbs were again a result of the cultivar's pungent parentage and its inherent limited ability to produce large bulbs.

The 10- and 12-week-old plants matured $\approx 1$ day earlier than the g-week-old plants. From a cultural standpoint, this does not mean

much, but the response was consistent enough to be significant. It was also expected because the 8-week-old plants were younger and smaller when planted in the field. Bulb fresh weight and yield of bulbs $\geq 76 \mathrm{~mm}$ in diameter increased linearly with age (Table 4). The increased weight in bulbs from 10 to 12 weeks

Table 3. Effects of cultivar, age, and $\mathrm{N}$ fertilization on seedling size and weight at transplanting.

\begin{tabular}{|c|c|c|c|c|}
\hline Variable & $\begin{array}{c}\text { Shoot ht } \\
(\mathrm{cm})\end{array}$ & $\begin{array}{c}\text { Shoot } \\
\text { fresh wt } \\
\text { (g) }\end{array}$ & $\begin{array}{c}\text { Root } \\
\text { fresh wt } \\
\text { (g) }\end{array}$ & $\begin{array}{c}\text { Root : shoot } \\
\text { ratio }^{2} \\
\text { (dry wt) }\end{array}$ \\
\hline \multicolumn{5}{|l|}{ Cultivar (C) } \\
\hline Sweet Sandwich & 13.1 & 1.05 & 0.41 & 0.34 \\
\hline Yula & 14.6 & 1.28 & 0.41 & 0.33 \\
\hline Vega & 14.1 & 1.25 & 0.43 & 0.32 \\
\hline LSD & 0.7 & 0.10 & NS & NS \\
\hline \multicolumn{5}{|l|}{ Seedling age (SA) } \\
\hline 8 weeks & 13.1 & 0.70 & 0.25 & 0.34 \\
\hline 10 weeks & 13.2 & 1.12 & 0.41 & 0.34 \\
\hline 12 weeks & 15.4 & 1.76 & 0.51 & 0.31 \\
\hline Significance & $\mathrm{L}^{* *} \mathrm{Q}^{* * *}$ & $\mathrm{~L}^{* *} \mathrm{Q}^{*}$ & $\mathbf{L}^{* *}$ & NS \\
\hline \multicolumn{5}{|l|}{ Contrasts } \\
\hline 8 vs. 10 & NS & ** & $* *$ & NS \\
\hline 10 vs. 12 & $* *$ & $* *$ & $* *$ & NS \\
\hline \multicolumn{5}{|l|}{ Nitrogen $(\mathrm{N})$} \\
\hline 75 ppm & 10.7 & 0.72 & 0.31 & 0.36 \\
\hline $150 \mathrm{ppm}$ & 13.9 & 1.20 & 0.43 & 0.33 \\
\hline 225 ppm & 17.2 & 1.66 & 0.51 & 0.29 \\
\hline Significance & $\mathrm{L}^{* *}$ & $L^{* *}$ & $\mathbf{L}^{* *}$ & $L^{* *}$ \\
\hline \multicolumn{5}{|l|}{ Contrasts } \\
\hline 75 vs. 150 & $* *$ & $* *$ & $* *$ & NS \\
\hline 150 vs. 225 & $* *$ & $* *$ & $* *$ & $*$ \\
\hline \multicolumn{5}{|l|}{ Interactions } \\
\hline $\mathrm{C} \times \mathrm{SA}$ & NS & ** & NS & $* *$ \\
\hline $\mathrm{C} \times \mathrm{N}$ & NS & NS & NS & NS \\
\hline $\mathbf{S A} \times \mathbf{N}$ & $* *$ & ** & NS & NS \\
\hline $\mathrm{C} \times \mathrm{SA} \times \mathrm{N}$ & NS & NS & NS & NS \\
\hline
\end{tabular}

${ }^{2}$ Each value is the mean of 360 plants.

Ns.*.** Nonsignificant or significant at $P=0.05$ or 0.01 , respectively. Linear (L) or quadratic (Q) response.

Table 4. Effects of cultivar, age, and $\mathrm{N}$ fertilization of seedlings on maturity, fresh weight, and bulb size of onions in the field.

\begin{tabular}{|c|c|c|c|c|c|c|c|c|}
\hline \multirow[b]{2}{*}{ Variable $^{x}$} & \multirow{2}{*}{$\begin{array}{l}\text { Maturity }^{z} \\
\text { (wk) }\end{array}$} & \multirow{2}{*}{$\begin{array}{c}\text { Bulb } \\
\text { fresh wt } \\
\text { (kg/plot) }\end{array}$} & \multicolumn{5}{|c|}{$\begin{array}{c}\text { Bulb size (mm) } \\
(\% \text { by wt at grading })^{y}\end{array}$} & \multirow{2}{*}{$\begin{array}{c}\text { Yield } \\
\text { of bulbs } \\
\geq 76 \mathrm{~mm} \\
\left(\mathrm{t} \cdot \mathrm{ha}^{-1}\right)\end{array}$} \\
\hline & & & $<76$ & $76-102$ & $>102-127$ & $>127$ & Cull & \\
\hline \multicolumn{9}{|l|}{ Cultivar } \\
\hline$S S^{w}$ & 15.5 & 31.2 & 1.1 & 76.0 & 20.1 & 0 & 2.8 & 35.1 \\
\hline Yula & 14.5 & 32.6 & 1.3 & 39.8 & 47.4 & 1.0 & 10.4 & 34.2 \\
\hline Vega & 16.0 & 33.9 & 1.2 & 49.8 & 44.4 & 0.6 & 4.1 & 37.5 \\
\hline LSD $(0.05)$ & 0.1 & 1.7 & NS & 2.9 & 3.1 & 0.8 & 2.0 & 1.2 \\
\hline \multicolumn{9}{|l|}{ Seedling age } \\
\hline 8 weeks & 15.4 & 31.1 & 1.7 & 59.1 & 33.4 & 0.5 & 5.3 & 34.1 \\
\hline 10 weeks & 15.3 & 33.0 & 1.1 & 56.0 & 36.6 & 0.4 & 5.9 & 36.0 \\
\hline 12 weeks & 15.3 & 33.7 & 0.7 & 50.6 & 41.9 & 0.7 & 6.1 & 36.8 \\
\hline Significance & $\mathrm{L}^{*}$ & $\mathrm{~L}^{* *}$ & $\mathrm{~L}^{* *}$ & $\mathrm{~L}^{* *}$ & $\mathrm{~L}^{* *}$ & NS & NS & $\mathrm{L}^{* *}$ \\
\hline \multicolumn{9}{|l|}{ Contrasts } \\
\hline 8 vs. 10 & NS & $* *$ & $*$ & NS & NS & NS & NS & $* *$ \\
\hline 10 vs. 12 & NS & NS & NS & $*$ & $* *$ & NS & $\mathrm{NS}$ & NS \\
\hline \multicolumn{9}{|l|}{ Nitrogen } \\
\hline 75 ppm & 15.6 & 30.8 & 1.7 & 60.9 & 31.7 & 0.4 & 5.2 & 33.7 \\
\hline $150 \mathrm{ppm}$ & 15.3 & 33.0 & 0.9 & 53.7 & 38.9 & 0.6 & 5.9 & 36.4 \\
\hline 225 ppm & 15.1 & 33.9 & 1.0 & 51.0 & 41.3 & 0.5 & 6.1 & 36.8 \\
\hline Significance & $\mathrm{L}^{* *}$ & $\mathrm{~L}^{* *}$ & $\mathbf{L}^{*}$ & $\mathrm{~L}^{* *}$ & $\mathrm{~L}^{* *}$ & NS & NS & $\mathrm{L}^{* *} \mathrm{Q}^{*}$ \\
\hline \multicolumn{9}{|l|}{ Contrasts } \\
\hline 75 vs. 150 & $* *$ & $* *$ & NS & $* *$ & $* *$ & NS & NS & $* *$ \\
\hline 150 vs. 225 & $*$ & NS & NS & NS & NS & NS & NS & NS \\
\hline
\end{tabular}

${ }^{2}$ Maturity defined as $25 \%$ of leaves lying down.

yercentage data were transformed by $\sqrt{(y+1)}$ for analysis; actual values are presented.

'Interactions between main effects were not significant.

"SS = 'Sweet Sandwich'.

Ns.****Nonsignificant or significant at $P=0.05$ or 0.01 , respectively. Linear (L) or quadratic (Q) response. was not significant, a fact that indicated that yields leveled off.

The percentage of bulbs $<76 \mathrm{~mm}$ and 76 to $102 \mathrm{~mm}$ in diameter decreased linearly with increasing plant age, and the percentage of bulbs $>102$ to $127 \mathrm{~mm}$ and yield of bulbs $\geq 76$ $\mathrm{mm}$ in diameter increased linearly (Table 4). Thus, although the bulbs matured at about the same time, the older plants produced larger bulbs. Kato (1964) and Sabota and Downes (1981) reported that larger onion plants at transplanting resulted in larger bulbs at harvest.

Bulbs matured earlier as greenhouse $\mathrm{N}$ applications increased from 75 to $225 \mathrm{ppm}$, although the differences in maturity were only a few days (Table 4). Bulb fresh weight and yield of bulbs $\geq 76 \mathrm{~mm}$ in diameter also increased linearly; the largest increase occurred with 75 to $150 \mathrm{ppm} \mathrm{N}$. The percentage of bulbs $<76 \mathrm{~mm}$ and 76 to $102 \mathrm{~mm}$ in diameter decreased linearly, and the percentage of bulbs $>102$ to $127 \mathrm{~mm}$ in diameter increased linearly. Yields of bulbs $\geq 76 \mathrm{~mm}$ in diameter also showed a. significant negative quadratic response, which indicates that yield of these large bulbs leveled off at the high $\mathrm{N}$ level.

The highest $\mathrm{N}$ level $(225 \mathrm{ppm})$ produced the largest seedlings and ultimately the largest bulbs at harvest (Table 4). However, the increase in yield of bulbs $\geq 76 \mathrm{~mm}$ in diameter at $>150$ ppm N was not significant. An N application rate of $150 \mathrm{ppm}$ may be optimum for onion transplant production.

Local production of onion transplants in the greenhouse may be a viable option for onion growers. By growing two plants in each cell, growers can optimize the yield of bulbs $\geq 76 \mathrm{~mm}$ in diameter, while not adversely affecting bulb shape.

Growers can sow onion seeds in the greenhouse over several weeks and plant them in the field 10 to 12 weeks after seeding. If weather permits early planting, plants as young as 8 weeks can be successfully established. If the weather precludes planting in the field, plants can be held in the greenhouse with no adverse effects and the potential for larger bulbs at harvest.

\section{Literature Cited}

Chung, B. 1989. Multi-plant module transplants of bulb onions. Acta Hort. 247:187-191.

Davis, G.N. and H.A. Jones. 1944. Experiments with the transplant onion crop in California. Calif. Agr. Expt. Sta., Davis, Bul. 682.

Jones, H.A. 1930. Spacing, time-of-planting, and size-of-seedling studies with the California Early Red onion. Proc. Amer. Soc. Hort. Sci. 26:114118.

Kato, T. 1964. Physiological studies on the bulbing and dormancy of onion plants. III. Effects of external factors on the bulb formation and development. J. Jpn. Soc. Hort. Sci. 33(1):53-61.

McGeary, D.J. 1985. The effect of plant density on shape, size, uniformity, soluble solids content, and yield of onions suitable for pickling. J. Hort. Sci. 60:83-87.

Sabota, C.M. and J.D. Downes. 1981. Onion growth and yield in relation to transplant pruning, size, and depth of planting. HortScience 16(4):533535 . 